\title{
RANCANG BANGUN SISTEM INFORMASI GEOGRAFIS (SIG) LOKASI PRAKTEK KERJA INDUSTRI (PRAKERIN) SMK METHODIST MEDAN BERBASIS WEB
}

\author{
${ }^{1)}$ Imam Rangga Bakti, ${ }^{2)}$ Yola Permata Bunda, ${ }^{3)}$ Cut Try Utari \\ ${ }^{1,2,3)}$ Sistem Informasi, Fakultas Teknik, Universitas Tjut Nyak Dhien \\ 1,2,3) Jln Gatot Subroto / Rasmi No. 28 Medan - Sumatera Utara - Indonesia \\ E-mail : imamranggabakti@gmail.com,yolapermata07@gmal.com,tarie.try91@gmail.com
}

\begin{abstract}
ABSTRAK
Sistem Informasi Geografis (SIG) adalah sebuah sistem informasi yang berbasiskan komputer didalam menyimpan, menganalisis dan mengelola serta memanggil data yang bersifat geografis dimana sistem ini berkembang pesat didalam lima tahun terkahir. Pada penelitian ini peneliti akan membangun aplikasi sistem informasi geografis praktek kerja indutri (PRAKERIN) dengan memanfaatkan pemetaan lokasi untuk memudahkan siswa dalam melakukan dan mendapatkan informasi seputar praktek kerja industri (PRAKERIN) yang ditentukan oleh pihak sekolah SMK Methodist Medan. Dalam pembangunan sistem ini nantinya peneliti menggunakan beberapa tools dan bahasa pemograman seperti Vscode sebagai text editor PHP sebagai bahasa pemograman $\mathrm{MySql}$ sebagai database untuk penyimpanan datanya serta googlemaps untuk membantu menampilkan peta dan live locationnya. Tujuan dari penelitian ini untuk mempermudah siswa dalam mengetahui lokasi prakerin serta informasi seputar prakerin. Metode penelitian yang digunakan adalah metode studi pustaka dan observasi,dimana data yang didapatkan dianalisis dengan menggnakan metode SLDC. Dalam penelitian ini hasil yang di dadapakan nantinya siswa bisa dapat dengan mudah menerima informasi seputar praktek kerja industri (PRAKERIN) di SMK Methodist Medan.
\end{abstract}

Kata Kunci: SIG, Sistem, PHP, MySql, GoogleMaps, Prakerin

\begin{abstract}
System Information Geographical (SIG) in one of based information system for storing, managing, and analzing, aw well as retrieving geograpchical referenced data that develope rapidly in the last five years. in this research, reseachers will build a geographical information system application for industrial work practice bby utilyzing location mapping to facilitate students in conducting and obtaining information about industrial work practices that is determined by SMK Methodist Medan. In the development of this system the research wil use some tods and programming languange such as Vscode as a text editor, PHP as programming language MySql as a database for data storage and googlemaps to help display map and live location.The purpose of this research is to make it easier for students to find out the location of internship and information about internship. The research method used is the method of literature study and observation, where the data obtained were analyzed using the SLDC method. In this research, the results of the students can easily receive information about industrial work practices at SMK Methodist Medan.
\end{abstract}

Keyword: SIG, System, PHP, MySql, GoogleMaps, Prakerin.

\section{PENDAHULUAN}

Sistem Informasi Geografis (SIG) adalah sebuah sistem informasi yang berbasiskan komputer didalam menyimpan, menganalisis dan mengelola serta memanggil data yang bersifat geografis dimana sistem ini berkembang pesat didalam lima tahun terkahir. SIG ini memiliki manfaat didalam memberikan kemudahan kepada pengguna atau pengambil keputusan didalam menentukan suatu kebijaksanaan yang akan diambil, terkhususnya yang terkait dengan aspek spasial (keruangan).
Kebutuhan Sistem Informasi mengenai geografis ini sangat dibutuhkan oleh beberapa banyak kalangan masyarakat atau instansi instasi misalnya informasi seputar jarak antar daerah, fasilitas, lokasi dan banyak informasi lainnya. Informasi tersebut sangat diperlukan pengguna didalam berbagai keperluanatau kebutuhan seperti penelitian, perancangan, pengembangan wilayah serta manajemen sumber daya alam. Dikarenakan dengan adanya geografis ini bisa membantu didalam penyajian suatu informasi peta yang lebih interaktif, 
dimana para pengguna dapat melakukan akses informasi geografis yang lengkap hanya dengan menggunakan smartphone atau komputer, webbrowser dan jaringan internet

SMK Methodist Medan sebagai salah satu sekolah kejuaruan atau vokasi yang memiliki program keahlian yang terdiri dari beberapa jurusan dalam mencetak para calon siswa yang professional di bidangnya. SMK Methodist Medan mempunyai program wajib untuk semua siswanya yaitu Praktek Kerja Industri (PRAKERIN) sebagai bentuk dari penambah wawasan tentang dunia kerja dan implementasi ilmu yang akan mereka hadapi untuk kedepannya. seperti pelatihan dan pembelajaran yang dilaksanakan di Dunia Usaha Atau Dunia Industri untuk upaya pendekatan ataupun untuk peningkatan mutu tamatan dengan kemampuan sesuai dengan bidangnya serta juga untuk menambah bekal dimasa yang akan mendatang guna memasuki dunia kerja yang semakin sulit dikarenakan banyaknya persaingan yang ketat di saat sekarang ini.

Dalam hal ini pihak sekolah akan mendistribusikan siswanya ke instansi permerintahan maupun swasta untuk melakukan Prakerin seperti kantor pemerintahan, perusahaan, industri, institusi pendidikan, perbankan, travel, bandara dan hotel yang sudah bekerja sama dengan pihak sekolah.

Penelitian yang sama atau sebelumnya tentang sistem informasi geografis sudah dilakukan oleh chaidir dkk, pada tahun 2019 Perancangan Sistem Informasi Geografis (Sig) Sebagai Media Informasi Prakerin Berbasis Web Di Smkn 6 Tangerang Selatan. Dari penelitian ini menghasilkan suatu sistem yang dapat menentukan lokasi praktek kerja insdustri untuk siswa dan siswa Smkn 6 tangerang [3]. Penelitian tentang sistem informasi geografis lainnya juga pernah dilakukan oleh setiyo dkk, pada tahun 2018 berjudul Sistem Informasi Geografis Tempat Penting Pantura Tegal Semarang Berbasis Web, dimana penelitian ini bertujuan untuk memetakan tempat penting yang ada disekitar jalur pantura TegalSemarang seperti SPBU, Rest Area, Bengkel, Kantor dan Pos Polisi, serta Rumah Sakit[8].

\section{METODE}

\section{Kerangka Kerja Penelitian}

Didalam penelitian ini akan diuraikan kerangka kerja penelitian yang dipergunakan untuk penyelesaian penelitian ini. Kerangka kerja penelitian disini adalah suatu langkahlangkah yang akan dilaksanakan didalam rangka menyelesaikan masalah yang dibahas. Adapun tahap-tahap didalam Siklus Pengembang Sistem atau System Development Life Cycle ( SDLC ) sebagai berikut:.

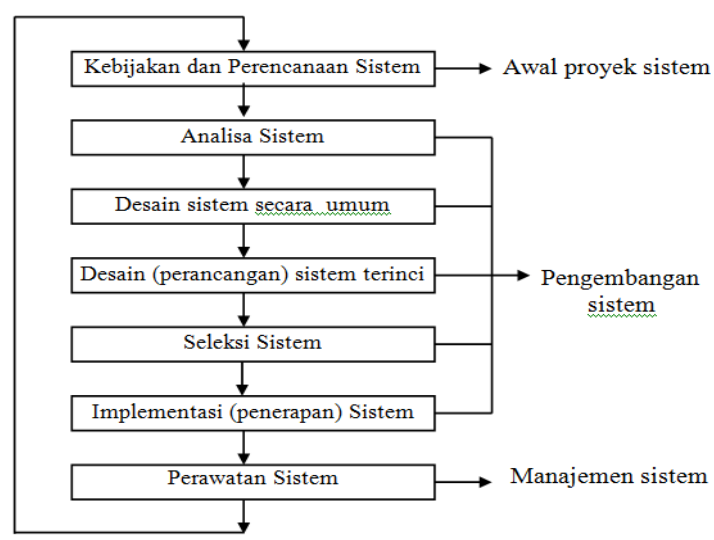

Gambar 1. Kerangka Kerja Penelitian

\section{a. Analisa Masalah}

Ada 3 tahap dalam melakukan analisa masalah pada penelitian ini yaitu :

1. Identify Step : melakukan identifikasi masalah yang sedang terjadi

2. Understand Step : pemahanan lanjutan dari permasalahan yang ada dengan melakukan pengumpulan data yang diperlukan.

3. Analyze Step : melihat segi kelemahan atau kekurangan dari sistem 
yang ada dan melakukan pengumpulan informasi informasi untuk kebutuhan selanjutnya.

\section{b. Pengumpulan Data}

Didalam pelaksanaan pengumpulan data pada penelitian ini dimaksudkan untuk dapat memperoleh data serta informasi secara langsung dari instasi terkait dan juga dari jaringan internet. Teknik yang dilakukan pada pengumpulan data disini dengan melaukan pengamatan dan wawancara oleh pihak instansi terkait.

\section{c. Peracangan Input/ouput Sistem}

Pada tahapan ini peneliti melakukan perancangan sistem dengan menggunakan dengan menggunakan tools yools yang berkaitan untuk tahap perancangan $\mathrm{i} / \mathrm{o}$ sistem

\section{d. Implementasi Sistem}

Pada tahap ini peneliti akan melakukan implemetasi atau pengoperasian Sistem Informasi Geografis (SIG) Lokasi Praktek Kerja Industri (PRAKERIN) Berbasis Web.

\section{HASIL}

\section{Gambaran Umum Sistem}

Pada gambaran umum sistem yang di buat pada penelitian ini ada 2 user pengguna dimana user pertama adalah admin sekolah dan User kedua merupakan siswa/siswi yang terdata disekolah, dimana disini Admin merupakan administrator yang memiliki hak untuk pengaksesan didalam pengelolaan sistem seperti menambah, melihat, menghapus, mengedit serta mencari data dan user siswa yang hanya bisa mengasek untuk melakukan pencarian data dan informasi melalui jaringan internet, menerima informasi legenda data berupa peta, dan informasi lain yang berkaitan dengan informasi pendataan pada Sistem Informasi Geografis Praktek Kerja Industri (PRAKERIN).

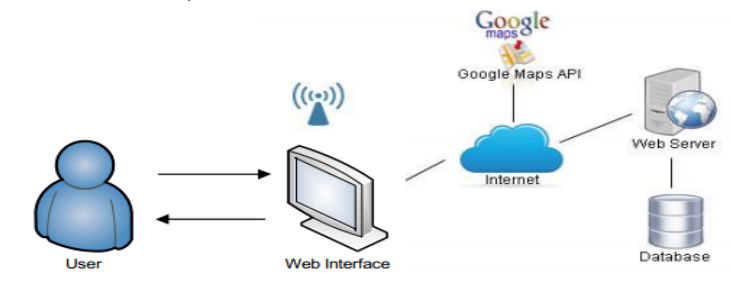

Gambar 2 Asitektur Sistem

Sedangkan gambaran dari arsitektur perangkat lunak dari Sistem Informasi Geografis Praktek Kerja Industri (PRAKERIN) adalah sebagai berikut :

Tabel 1. Arsitektur Perangkat L

\begin{tabular}{|c|c|c|}
\hline Dimensi & Tugas & Hak \\
\hline $\begin{array}{l}\text { Administ } \\
\text { rator }\end{array}$ & $\begin{array}{l}\text { Mengelo } \\
\text { la SIG } \\
\text { Praktek } \\
\text { Kerja } \\
\text { Indutri }\end{array}$ & $\begin{array}{l}\text { - Menambah } \\
\text { Melihat dan } \\
\text { menghapus data } \\
\text { user. } \\
\text { - Melihat dan } \\
\text { menghapus data } \\
\text { - Memberikan } \\
\text { konfirmasi } \\
\text { melalui web } \\
\text { tentang data peta } \\
\text { penambahan } \\
\text { informasi peta, edit } \\
\text { dan update data } \\
\text { - Mengelola data } \\
\text { peta, kategori, } \\
\text { legenda peta }\end{array}$ \\
\hline User & & $\begin{array}{l}\text { - siswa dapat } \\
\text { melihat informasi } \\
\text { yang disajikan } \\
\text { system } \\
\text { - siswa bisa lebih } \\
\text { detail semua data } \\
\text { informasi geografis } \\
\text { secara online yang } \\
\text { disajikan melalui } \\
\text { peta digital yang } \\
\text { tekoneksi ke } \\
\text { Google Map }\end{array}$ \\
\hline
\end{tabular}




\section{Prosedur Sistem yang diusulkan}

Admin mengelola sistem, dan menginformasikan data kedalam peta sesuai dengan sesuai dengan yang data yang berkemabang, menginformasikan kepada konsumen tentang informasi peta digital secara online, data lokasi tempat prakerin, tata cara magang, panduan praktek, penilaian. User atau siswa mengakses situs dari Sistem Informasi Geografis Praktek Kerja Industri dan bisa melihat secara detail dan tergambar didalam peta penyajian informai dari sistem Informasi sesuai data yang ada dilapangan kepada user/siswa sesuai dengan informasi yang disediakan.

\section{Usecase Diagram}

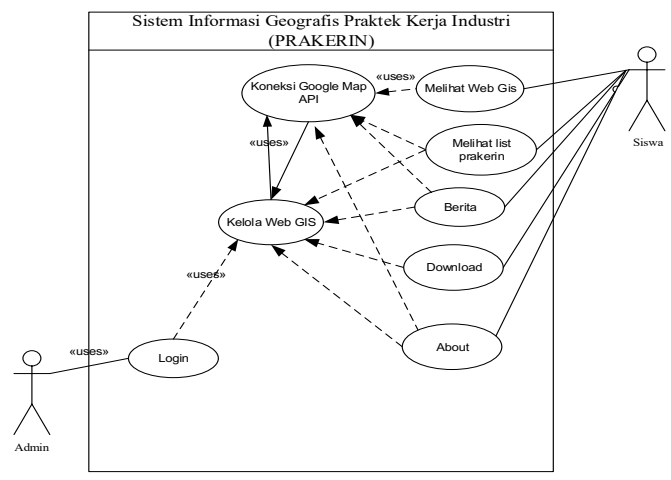

Gambar 4 Usecase Diagram

Didalam sistem yang dibuat ini memiliki dua aktor dimana aktor pertama adalah user dan yang kedua adalah admin. Kegiatan atau hak yang dapat diperbuat atau dilakukan oleh user adalah melihat peta, melihat list prakerin, berita, dowload dan about. Sedangkan hak atau kegiatan yang bisa diperbuat terhdap admin pada sistem adalah login dan mengelola data Sistem Informasi Geografis Praktek Kerja Industri (PRAKERIN).

\section{Implementasi Program}

Pada implementasi program disini akan menampilkan menu menu enu atau design interface dari sistem yang telah dibuat. a. Halaman Utama SIG Prakerin

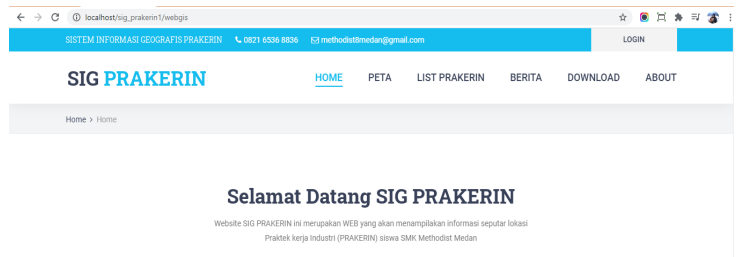

Gambar 5 Halaman Utama SIG Prakerin

Pada halaman ini akan menampilkan halaman utama yang bisa di akses oleh user.

b. Halaman Peta Lokasi

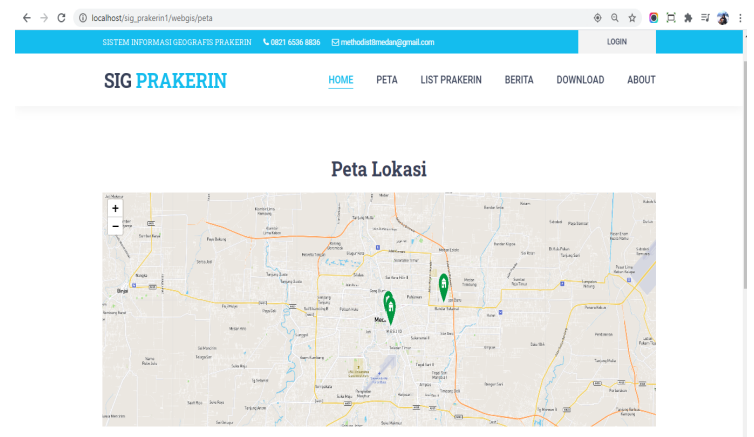

Gambar 6 Peta Lokasi

Pada tampilan halaman ini akan menampilkan peta lokasi keseluruhan lokasi prakerin

c. Halaman List Prakerin

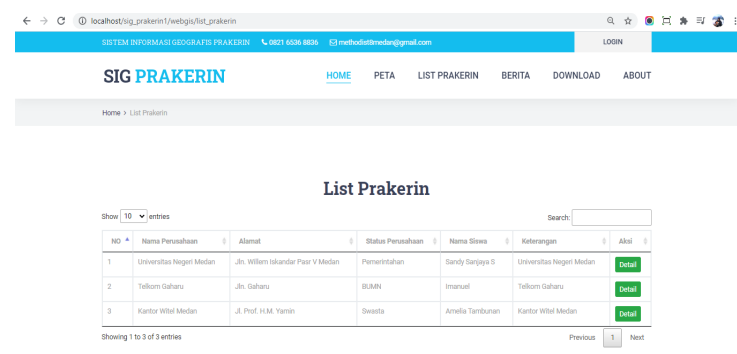

Gambar 7 Halaman List Prakerin

Pada tampilan halaman ini akan menampilkan data data siswa yang melakukan prakerin.

d. Halaman Detail List Lokasi Prakerin 


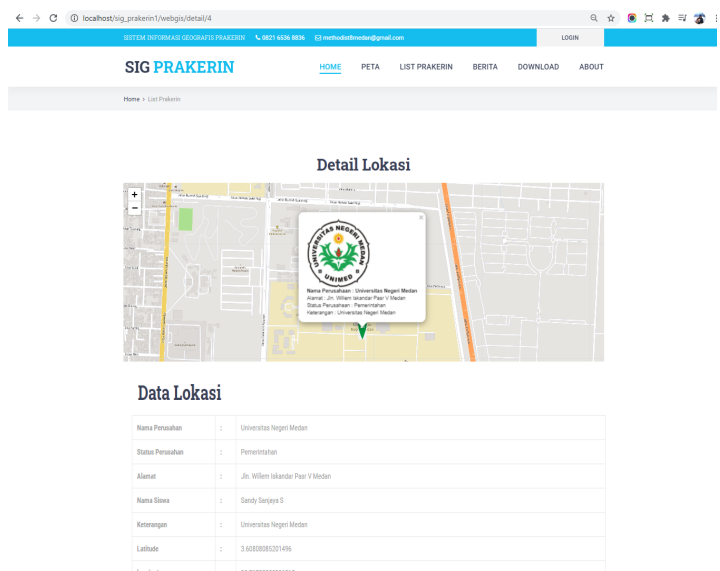

Gambar 8 Halaman Detail List Lokasi Prakerin

Pada tampilan halaman ini akan menampilkan detail data siswa yang melakukan prakerin

e. Halaman Berita

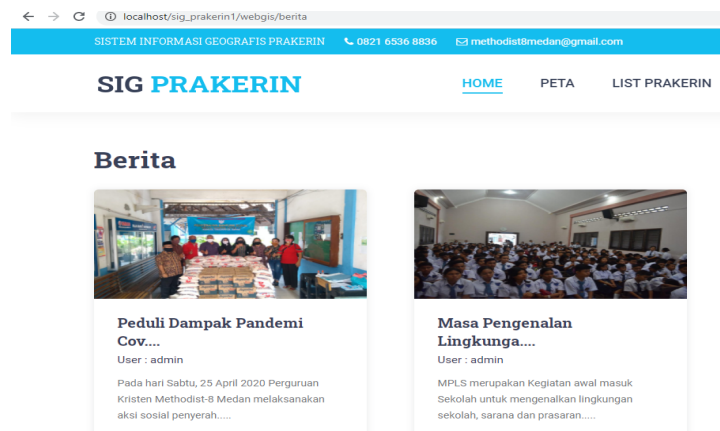

Gambar 9 Halaman Berita

Pada halaman ini akan menampilkan berita seputar informasi sekolah dan prakerin

\section{f. Halaman Login Admin}

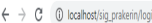

GIS PRAKERIN : Login

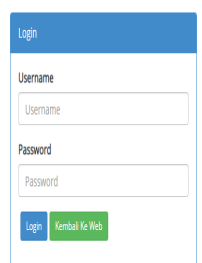

Gambar. 10 Halaman Login Admin

Pada halaman ini akan menampilkan menu untuk melakukan login ke menu admin.

g. Halaman Admin

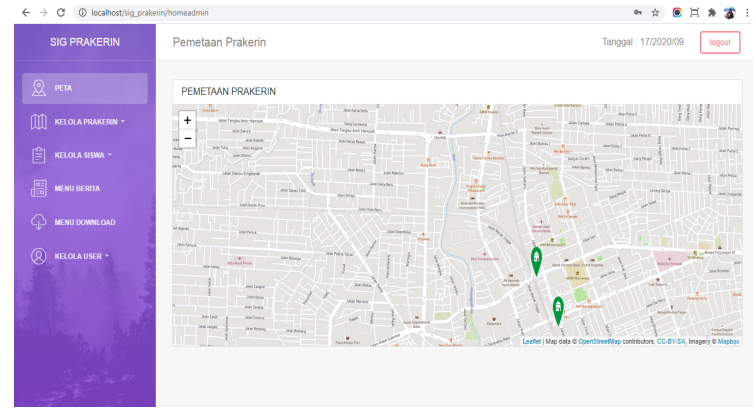

Gambar. 11 Halaman Admin

Pada halaman ini akan menampilkan seluruh menu yang bisa di akses oleh admin.

h. Halaman Input Lokasi Prakerin

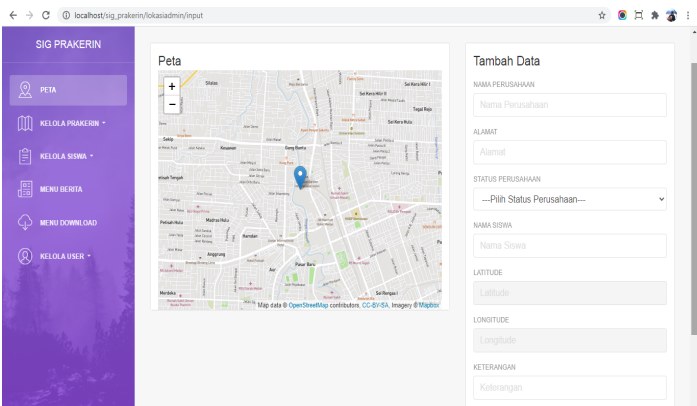

Gambar. 12 Halaman Input Lokasi Prakerin

Pada halaman ini akan menampilkan menu untuk melakukan pengiputan data siswa yang prakerin

i. Halaman Rute

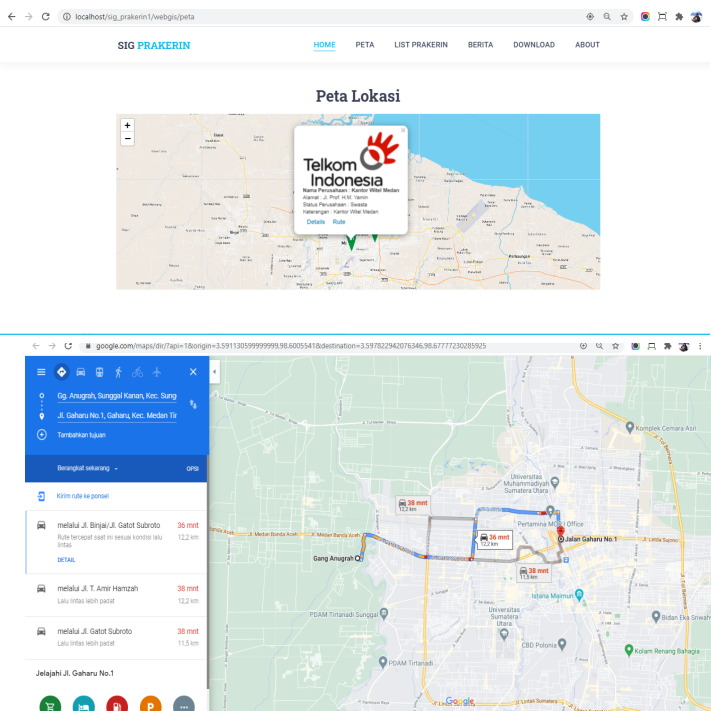

Gambar. 13 Halaman Rute 
Pada halaman ini ketika user melakukan klik rute akan menampilkan jalur rute tujuan dan live location user berada.

\section{KESIMPULAN}

Hasil dari pada penelitian yang telah dilaksanakan disini, dapat ditarik kesimpulan bahwa dengan adanya aplikasi sistem informasi geografis prakerin disini dapat memudahakan siswa yang belum mengenal kawasan atau daerah lokasi prakerin untuk untuk mencari lokasi prakerinnya, dan dengan adanya sistem informasi geografis prakerin ini juga memudahkan untuk mendapatkan informasi lokasi prakerin secari rinci dan jelas dan memudahkan untuk memonitor perkembangan siswa prakerin sewaktu melaksanakan prakerin.

\section{UCAPAN TERIMAKASIH}

Terima kasih kepada Kemendikbud melalui DRPM DIKTI yang telah memberikan dana dalam penelitian untuk tahun 2020

\section{DAFTAR PUSTAKA}

[1] Abdul Kadir. 2002. Pengenalan Sistem Informasi. Andi. Yogyakarta.

[2] C. K. Thoullah, A. Bilqisti, and D. Alifiyanto, "Perancangan Sistem Infomasi Geografis Sebagai Media Informasi Prakerin Berbasis Web Di Smkn 6 Tangerang Selatan," vol. 5, no. 1, pp. 5567, 2019.

[3] I. R. Bakti, "Sistem Informasi Geografis Jaringan Irigasi Dinas Bina Marga Dan Pengairan Kabupaten Rohil," Jursima, vol. 7, no. 1, p. 12, 2019, doi: 10.47024/js.v7il.162.

[4] R. FAJRIN, "Pengembangan Sistem Informasi Geografis Berbasis Node.JS untuk Pemetaan Mesin dan Tracking Engineer dengan Pemanfaatan Geolocation pada PT IBM Indonesia,” J. Inform., vol. 11, no. 2, pp. 33-40, 2017, doi: 10.26555/jifo.v11i2.a6090.
[5] M. A. Husaini and W. Dwi P, "Sistem Informasi Geografis (Sig) Pemetaan Sekolah Berbasis Web Di Kecamatan Wonodadi Kabupaten Blitar," ANTIVIRUS J. Ilm. Tek. Inform., vol. 11, no. 1, pp. 50-64, 2017, doi: 10.30957/antivirus.v11i1.198.

[6] S. H. Putra, "Pemanfaatan Sistem Informasi Geografis Dalam Pengembangan Pariwisata Di Kawasan Wisata Kabupaten Langkat," vol. 2, pp. 67-80, 2020.

[7] G. W. Sasmito, "Penerapan Metode Waterfall Pada Desain Sistem Informasi Geografis Industri Kabupaten Tegal," J. Inform. Pengemb. IT, vol. 2, no. 1, pp. 612, 2017.

[8] M. D. Setiyo, S. Kom, and S. Wibowo, "Sistem Informasi Geografis Tempat Penting Pantura Tegal- Semarang ( SIG TEPI Pantura Terang ) Berbasis Web," no. 1, pp. 46-55, 2018.

[9] Prahasta, Eddy. 2002. Konsep-konsep Dasar Sistem Informasi Geografis. Informatika: Bandung

[10]Rismayani, "Pemanfaatan Teknologi Goole Maps Api Untuk Aplikasi Laporan Kriminal Berbasis Android Pada Polrestabes Makassar," J. Penelit. Pos Dan Inform., Vol. 6, No. 2, Pp. 185200, 2016. 